\title{
均一沈殿法によるネオジム化合物の合成と焼結
}

\author{
渡邊恵美・伊熊泰郎 \\ 神奈川工科大学応用化学科, 243-02 厚木市下荻野 1030

\section{Synthesis and Sintering of Neodymium Compounds Prepared by Homogeneous Precipitation Method} \\ Emi WATANABE and Yasuro IKUMA \\ Kanagawa Institute of Technology, 1030, Simoogino, Atsugi-shi, Kanagawa 243-02

\begin{abstract}
Neodymium compounds were prepared by mixing $\mathrm{Nd}\left(\mathrm{NO}_{3}\right)_{3}$ solution with hexamethylenetetramine (HMT), urea and $\mathrm{NH}_{4} \mathrm{OH}$. The precipitates were characterized by TG-DTA, X-ray powder diffraction, IR and SEM. The composition of precipitate formed by the HMT method was $\mathrm{Nd}(\mathrm{OH})_{3}$ and that by the urea method was $\mathrm{NdCO}_{3} \mathrm{OH}$. The difference in chemical composition was due to the presence of $\mathrm{CO}_{2}$ in the decomposition product of urea. The particle size of precipitate by the HMT method was uniform but smaller than that by the urea method. Consequently, the powder formed by HMT method was sintered to the highest density at $1300^{\circ} \mathrm{C}$.

[Received March 14, 1997; Accepted July 4, 1997]
\end{abstract}

Key-words : Homogeneous precipitation method, $\mathrm{Nd}(\mathrm{OH})_{3}, \mathrm{NdCO} \mathrm{CH}_{3} \mathrm{OHd} \mathrm{O}_{3}$, Hexamethylenetetramine, Urea

\section{1. 緒 言}

セラミックス多結晶体は通常粉末を焼結して作られるので, 焼結の良し悪しは用いる粉末によって左右される。工業的に良 い焼結粉末は，適切な形と分布をしていること，できるだけ低 温でのか焼により最終的化学組成(例えば酸化物)になること, 調製方法が単純で安価であること，などが要求される．この中 でも粉末の形状と分布は重要で，均一な大きさの球状粒子1),2) が高密度化に適していることが知られている。

単純で安価に粉末を合成する方法として，溶液中に存在する 陽イオン（金属イオン）を，水酸化物，シュウ酸塩等として沈 殿させ，これらの熱分解によって酸化物を得ることが昔から行 われている．この方法では，例えば可溶性塩の溶液にアンモニ アを混合することによって沈殿を生成するが，混合された部分 で直ちに沈殿の生成が始まり, 溶液が不均一になるため, 細か い粒子やその凝集体が発生する。このように，不均一な大きさ の粉末が得られるので, 良い沈殿をつくるために, 希薄な溶液 を少しずつ混合することが行われてきた。

このような局部的沈殿を避けるには，溶液濃度や $\mathrm{pH}$ を均一 に保つことが必要である。 その方法として, 適当な化学反応に よって, 沈殿を生成する状態を溶液内に均一に起こす均一沈殿 法3)がある。この方法で合成された沈殿物は, 均一な大きさの ものとなりやすい。したがって，焼結性の良いセラミックス原 料粉末が得られることが予想される。

均一沈殿法の中でも古くから研究されているのは, 沈殿剂に 尿素を用いた尿素加水分解法3)である.この方法でアルミニウ 么の化合物を合成することは，何十年も前4)に行われ，最近で は Cornilsen と Reed ${ }^{5)}$ や Blendell $5^{6)}$ も球状の塩基性硫酸了ル ミニウムを合成している。永島ら7)はこの方法を用いてチタン 酸アルミニウムを作製し, 焼結性を研究した。また, Akinc と Sordelet ${ }^{8)}$ は，この方法によりネオジム，セリウム，イットリ ウムなどの希土類化合物の合成を行い, 粉末形状の観察や評価 などから反応式を推測した，尿素はよく水に溶けるとともに加 熱によって，(1)式

$$
\mathrm{NH}_{2} \mathrm{CONH}_{2}+\mathrm{H}_{2} \mathrm{O} \rightarrow 2 \mathrm{NH}_{3}+\mathrm{CO}_{2}
$$

のように加水分解し, 溶液の $\mathrm{pH}$ を変化させる. 加水分解は $70^{\circ} \mathrm{C}$ 以上で認められる程度となり，90 $\mathrm{C}$ 以上でかなりの速さ
で進行する。加水分解が進行する上溶液の $\mathrm{pH}$ は上昇するが, 溶液を室温に冷却すれば $\mathrm{pH}$ の上昇は停止するので，任意の $\mathrm{pH}$ で沈殿反応を行うことができる.

水溶液中で分解してアンモニアを生成する物質は他にもあり, Fujita と Kayama $^{9}$ はへキサメチレンテトラミン (HMT) を 用いて酸化亜鉛を合成して抢り, Chen と Chen ${ }^{10)}$ は, 焼結性 の良い酸化セリウムを得ている. HMT 水溶液を加熱すると, (2) 式

$$
\left(\mathrm{CH}_{2}\right)_{6} \mathrm{~N}_{4}+6 \mathrm{H}_{2} \mathrm{O} \rightarrow 4 \mathrm{NH}_{3}+6 \mathrm{HCHO}
$$

に従って分解する。（1)式と (2) 式の生成物は異なるので，沈 殿剂に尿素を用いる場合と HMT を用いる場合では沈殿物の 化学組成が違ってくると考えられる。 また, 沈殿剤に $\mathrm{NH}_{4} \mathrm{OH}$ を用いた場合では, 混合点で濃度差が生じるため粒子の大きさ は不均一となるが, HMT 法では沈殿生成を起こさせるような 状態が溶液内に均一にできるので, 大きさや形の均一な粒子が 得られる3) と予想される.

希土類元素の化合物は母材としてだけでなく, 希土類元素を 含む複酸化物や添加剂として広く用いられているので, 用途に よってその粉末の形状や大きさの要求は異なる。したがうて, 希土類化合物は均一沈殿法の特性を調べるのに適した物質であ る。しかし，均一沈殿法により希土類化合物を合成した報 告8),10) は少なく, なた, 一つの元素で複数の均一沈殿法による 結果を比較した報告もない，そこで本研究では, 希土類元素の 中でも比較的生産量が多く, 工業的にも使用されやすいネオシ ムを用いた均一沈殿法などに扔いて, 沈殿㓮の種類（HMT， 尿素, $\left.\mathrm{NH}_{4} \mathrm{OH}\right)$ が生成物に与える影響を調べ，その生成物の 評価を行うとともに，焼結性を調べることを目的として行っ た.

\section{2. 実験方法}

$0.05 \mathrm{~mol} / 1$ の $\mathrm{Nd}\left(\mathrm{NO}_{3}\right)_{3}$ （レアメタリック）水溶液に, $0.2 \sim 2 \mathrm{~mol} / 1$ 尿素 (関東化学) 水溶液, $0.2 \sim 2 \mathrm{~mol} / 1$ の HMT (関東化学) 水溶液あるいは0.8 $8 \mathrm{~mol} / 1$ のアンモニア溶液 (富 山薬品工業）をそれぞれ混合し，HMT 法と尿素法では，かく はんしながらホットプレートを用いて平均昇温速度約 $2.5^{\circ} \mathrm{C} / \mathrm{min}$ で室温から $100^{\circ} \mathrm{C}$ な゙加熱してすぐに放冷し，アン 
モニア法では混合液を加熱しないでかくはんした，加熱する 々, 尿素やHMT H(1)式や(2) 式に従って分解され, アンモ ニアを生成してネオジム化合物が沈殿した．この沈殿物を吸引 沪過し, 純水で洗浄し, $85^{\circ} \mathrm{C}$ で約 $100 \mathrm{~h}$ 乾燥させ, 乳鉢で粉砕し 粉末試料を得た。

得られた粉末試料の一部をおのおの TG-DTA (理学電機製, Thermoflex TG 8110）にかけ，加熱による重量変化から調製 された試料の評価を行った. DTA 曲線のピークの前後の温度 に電気炉を用いて加熱し, 保持時間なしで冷却した試料の X 線回折（XRD : Philips 社製，PW-1840）及び, IR（島津製 作所製, IR-408), 走査型電子顕微鏡 (SEM ; 日本電子製, JSM-T20）観察を行った.

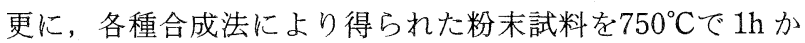
焼した後, 金型に入れ, $98 \mathrm{MPa}$ で $5 \mathrm{~min}, 1$ 軸加圧成形して錠 剤を作った。これらの錠剤を電気炉を用いて昇温速度 $10^{\circ} \mathrm{C} /$ $\min$ で1100 $1400^{\circ} \mathrm{C}$ に加熱し，そのまま $1 \mathrm{~h}$ 保持して焼結体試 料とした. その試料の重量と直径, 厚さを測定し, かさ密度を 計算した. 更に焼結体試料の破断面を SEM で観察することに より焼結状況を調べた。

\section{3. 結果と考察}

\section{1合成結果}

本研究の実験条件に対して, 尿素法, HMT 法, アンモニア 法では，すべて薄紫色の沈殿物が生成した。

尿素法では, 硝酸ネオジム水溶液に尿素水溶液を加えても常 温では沈殿物は生成しなかったが，この溶液をかくはん・加熱 すると, 約 $75^{\circ} \mathrm{C}$ ら徐々に白紫色の沈殿物が生じた。これは, 尿素の加水分解（(1) 式の反応) が約 $75^{\circ} \mathrm{C}$ で徐々に起こり，そ のとき生じた $\mathrm{NH}_{3}$ と硝酸ネオジムが反応したこ。が原因であ る。なお, 尿素の分解温度が HMT の分解温度より高いため, 尿素法での沈殿の生成速度は, HMT 法の場合より遅かった。

HMT 法では, 硝酸ネオジム水溶液に HMT 水溶液を加え常 温のままかくはんを行うと, 極微量の薄膜状の沈殿を生じた.

これは HMT 水溶液を調製する際, 反応熱（溶解が発熱反応） により水温が上昇し, 一部の HMT が分解して沈殿が生成し たためと思われる．この溶液をかくはん・加熱すると約 $40^{\circ} \mathrm{C}$ で一度に白紫色の沈殿物が生じた。これは, HMTの加水分解

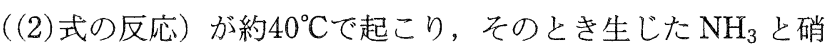
酸ネオジムが反応したことによる.

アンモニア法では, 硝酸ネオジム水溶液に $\mathrm{NH}_{4} \mathrm{OH}$ を加え るとすぐに常温で沈殿が生じた．これは局部沈殿である.

\section{2 試料の同定}

尿素法で合成した試料の TG-DTA 結果を図 1 に示す。この 試料を加熱すると重量は，ほほ２段階で変化することが分か る. 最初, $465^{\circ} \mathrm{C}$ に吸熱反応を伴う大きな重量減少があり, $640,705^{\circ} \mathrm{C}$ に吸熱反応を伴う小さな重量減少があった。これら の変化の前後の温度ごとに試料を加熱し X 線回折 (XRD) と IR を行った結果も図 1 に示す。これらの結果から次のことが 分かる. 沈殿生成物は, 常温では $\alpha-\mathrm{NdCO}_{3} \mathrm{OH}$ 結晶であり,

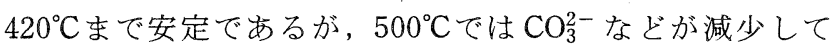
$\mathrm{Nd}_{2} \mathrm{O}_{2} \mathrm{CO}_{3}$ 結晶となり, $800^{\circ} \mathrm{C}$ 以上では $\mathrm{HMT}$ 法の場合とほぼ 同じで $\mathrm{Nd}_{2} \mathrm{O}_{3}$ 結晶（六方晶と立方晶の混合物）になり， $1200^{\circ} \mathrm{C}$ では六方晶 $\mathrm{Nd}_{2} \mathrm{O}_{3}$ 単相になった.

これらの結果とTG-DTAグラフを対応させてみると， $400 \sim 500^{\circ} \mathrm{C}$ で起こる重量減少（吸熱反応, $465^{\circ} \mathrm{C}$ ) は, $\alpha-$ $\mathrm{NdCO}_{3} \mathrm{OH}$ から $\mathrm{Nd}_{2} \mathrm{O}_{2} \mathrm{CO}_{3}$ への変化であると思われる。これ

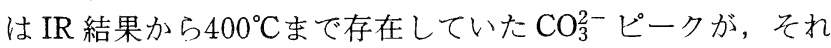
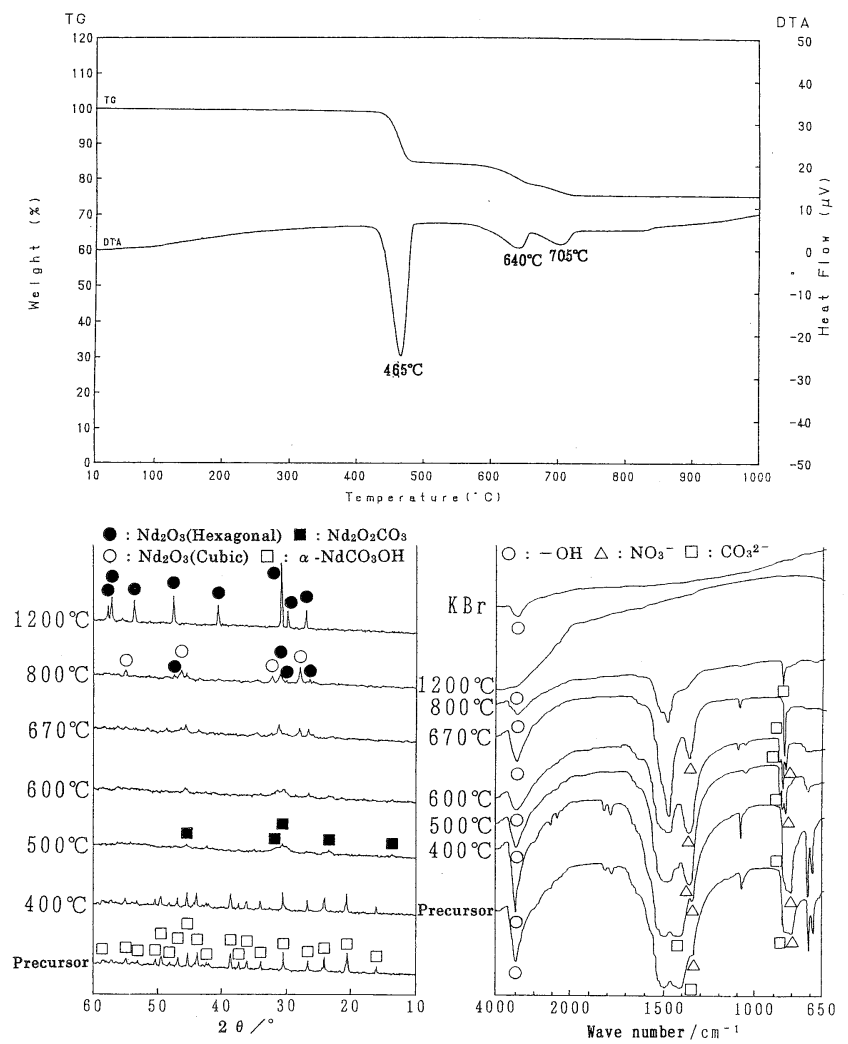

Fig. 1. TG-DTA, XRD and IR of precipitates obtained by the urea method.

以上では消えていることや, 重量減少の実験値（15.6\%減少） と理論值（13.6\%減少）がほぼ一致することで裏付けられる. $600 \sim 800^{\circ} \mathrm{C}$ で起こる重量減少（吸熱反応, $640,705^{\circ} \mathrm{C}$ ) は, $\mathrm{Nd}_{2} \mathrm{O}_{2} \mathrm{CO}_{3}$ から $\mathrm{Nd}_{2} \mathrm{O}_{3}$ への変化であり, これもなた, 実験值 (8.57\%減少) と理論值（5.62\%減少）がほぼ一致することで 裏付けられる.

これらの結果をまとめると, 尿素法では尿素の加水分解 ((1)式) を経て, (3)式

$$
\begin{gathered}
3 \mathrm{NH}_{3}+\mathrm{CO}_{2}+\mathrm{Nd}\left(\mathrm{NO}_{3}\right)_{3}+2 \mathrm{H}_{2} \mathrm{O} \\
\rightarrow \mathrm{NdCO}_{3} \mathrm{OH}+3 \mathrm{NH}_{4} \mathrm{NO}_{3}
\end{gathered}
$$

に示す反応で沈殿物が生成したと考えられる。更に，この沈殿 物を加熱すると, 2 段階の分解反応

$$
\begin{aligned}
& 2 \alpha-\mathrm{NdCO}_{3} \mathrm{OH} \rightarrow \mathrm{Nd}_{2} \mathrm{O}_{2} \mathrm{CO}_{3}+\mathrm{CO}_{2} \uparrow+\mathrm{H}_{2} \mathrm{O} \uparrow \\
& \mathrm{Nd}_{2} \mathrm{O}_{2} \mathrm{CO}_{3} \rightarrow \mathrm{Nd}_{2} \mathrm{O}_{3}+\mathrm{CO}_{2} \uparrow
\end{aligned}
$$

を経て酸化物になったと考えられる．尿素法については， Akinc と Sordelet ${ }^{8)}$ も報告しており，上の(4)，(5)式の反応は 彼らが提案している反応式と一致する。

HMT 法で合成した試料の TG-DTA 結果を図 2 に示す。こ の試料を加熱すると重量は，ほぼ 3 段階で変化することが分 かる. 最初, $300,326^{\circ} \mathrm{C}$ に吸熱反応を伴う重量減少があり, $420^{\circ} \mathrm{C}$ に発熱反応を伴う重量減少があり, $500 \sim 750^{\circ} \mathrm{C}$ で熱の出 入りのない重量減少があった。これらの変化の前後の温度ごと に試料を加熱しXRD とIR を行った結果も図 2 に示す。これ らの結果から次のことが分かる。常温では $\mathrm{Nd}(\mathrm{OH})_{3}$ 結晶で あったのが， $350 〜 380^{\circ} \mathrm{C}$ あ゙加熱すると分解しながらアモル ファスとなる。このとき $\mathrm{CO}_{3}^{2-}$ が少し現れる. $470^{\circ} \mathrm{C}$ な加熱 するとアモルファスのまま $\mathrm{CO}_{3}^{2-}$ が増え, 更に $800^{\circ} \mathrm{C} に$ 加熱す ると $\mathrm{CO}_{3}^{2-}, \mathrm{NO}_{3}^{-}, \mathrm{OH}^{-}$が減少するが，まだそれらを少し残し たまむ $\mathrm{Nd}_{2} \mathrm{O}_{3}$ 結晶（立方晶と六方晶の混合物）になり， $1200^{\circ} \mathrm{C}$ 

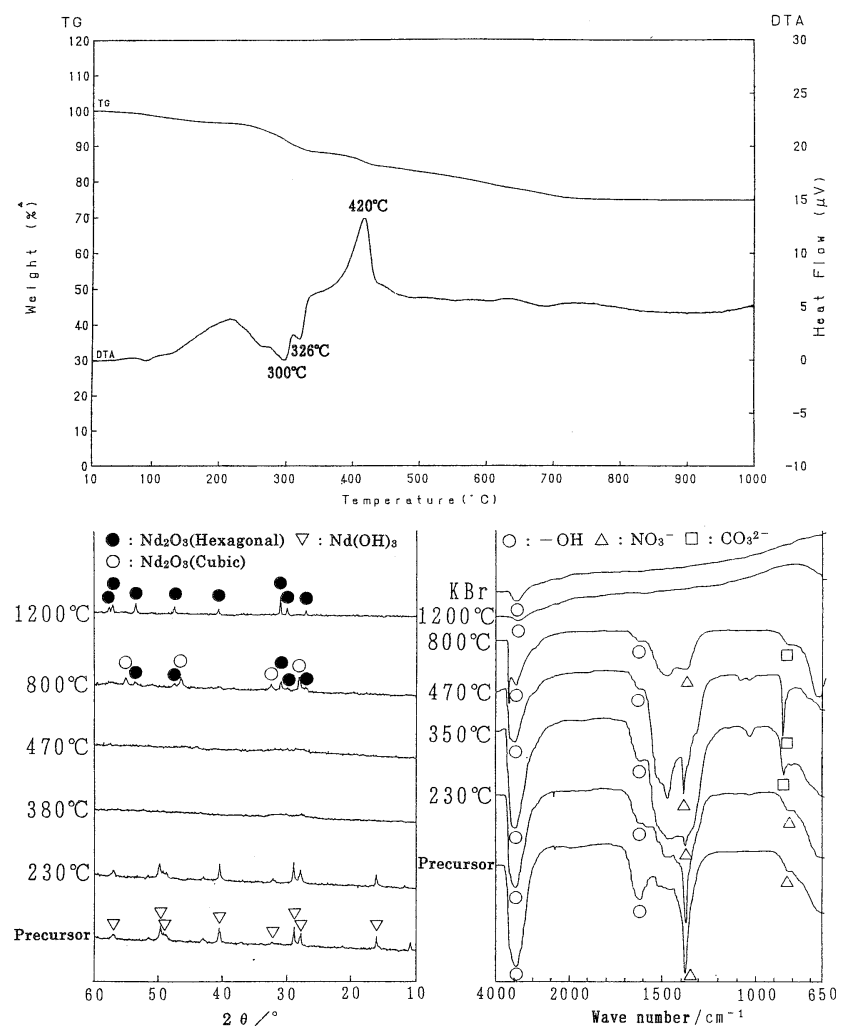

Fig. 2. TG-DTA, XRD and IR of precipitates obtained by the HMT method.

では $\mathrm{CO}_{3}^{2-}, \mathrm{NO}_{3}^{-}, \mathrm{OH}^{-}$が完全になくなって六方晶 $\mathrm{Nd}_{2} \mathrm{O}_{3}$ 単相 になることが分かった。

これらの結果と TG-DTAグラフを対応させてみると， $170^{\circ} \mathrm{C}$ までに起こる微量の重量減少 (吸熱反応) は, $\mathrm{Nd}(\mathrm{OH})_{3}$ 中の水分蒸発と思われる. $170 \sim 380^{\circ} \mathrm{C}$ で起こる重量減少（吸 熱反応, $\left.300,326^{\circ} \mathrm{C}\right)$ は, $\mathrm{Nd}(\mathrm{OH})_{3}$ から $\mathrm{Nd}_{2} \mathrm{O}_{3}$ への変化であ り, これは重量減少の実験値（8\%減少）と理論値（5.62\%減 少）がほぼ一致することで裏付けられる. $350^{\circ} \mathrm{C}$ の IR 結果で $\mathrm{CO}_{3}^{2-}$ ピークが突然発生していることから, 試料に付着してい

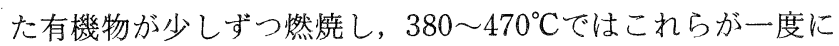
燃焼して発熱反応 $\left(420^{\circ} \mathrm{C}\right)$ を伴う重量減少があったため

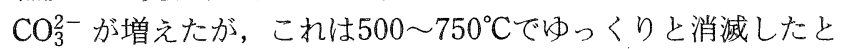
考えられる.

アンモニア法で合成した試料の TG-DTA 結果などを図 3 に 示す.アンモニア法の試料の XRD 結果は HMT 法のものと良 く似ている。しかし，アンモニア法の試料の TG-DTA 結果で は $420^{\circ} \mathrm{C}$ に発熱を伴う反応がない。これはアンモニア法の試料 では HMT 法の試料で存在するような有機物がなかったから で, アンモニア法の試料の IR 結果にも $\mathrm{CO}_{3}^{2-}$ の吸収がないこ とと良く対応する。つまり，アンモニア法とHMT 法の試料 の違いは, HMT 法のものには有機物が残っていたが, アンモ ニア法のものには有機物がないことである。これは，(2)式の 生成物の一つである $\mathrm{HCHO}$ が関係している。

図 2 と図 3 の結果をまとめると, 次のようになる.HMT で は加水分解（(2)式の反応）時に $\mathrm{CO}_{2}$ を発生しないため, 尿素 法とは異なる沈殿が生成し, HMT 法の沈殿物はアンモニア法 のものと同じになった。すなわち, HMT 法とアンモニア法で は, (6)式

$$
3 \mathrm{NH}_{3}+\mathrm{Nd}\left(\mathrm{NO}_{3}\right)_{3}+3 \mathrm{H}_{2} \mathrm{O} \rightarrow \mathrm{Nd}(\mathrm{OH})_{3}+3 \mathrm{NH}_{4} \mathrm{NO}_{3}
$$

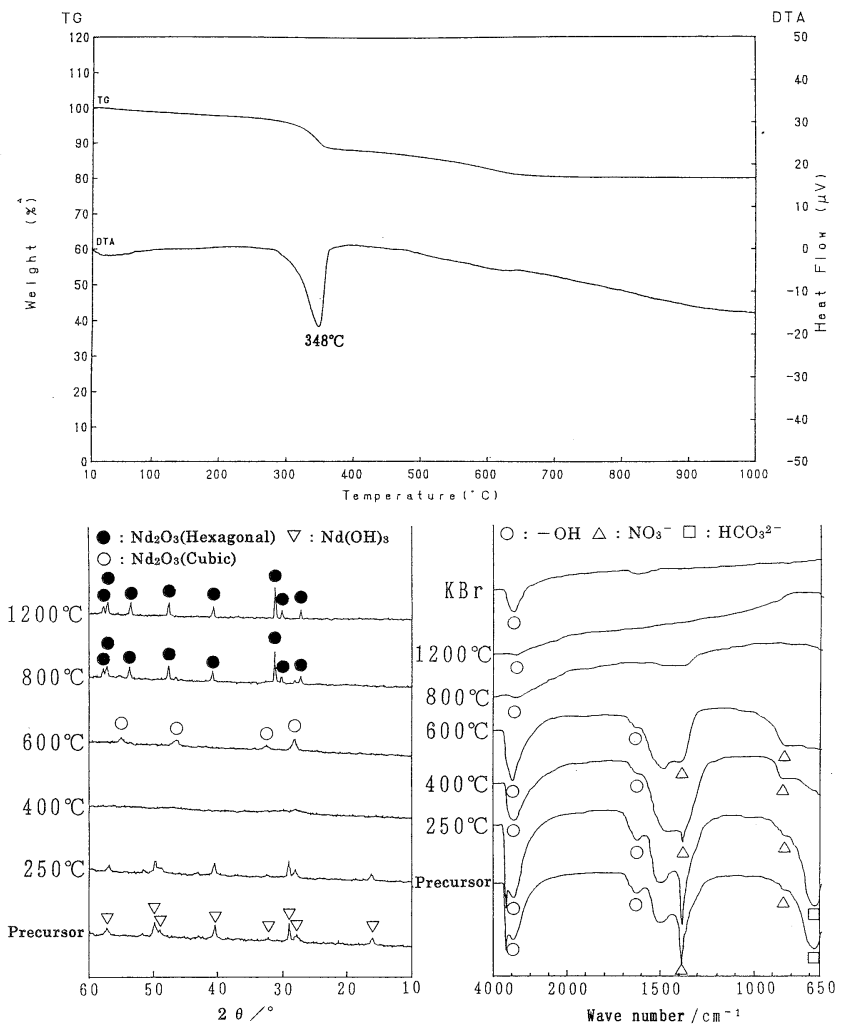

Fig. 3. TG-DTA, XRD and IR of precipitates obtained by the $\mathrm{NH}_{4} \mathrm{OH}$ method.

に示す反応で沈殿物が生成したと考えられる．更に，この沈殿 物を加熱すると, HMT 法とアンモニア法の試料は，ほぼ同様 の 1 段階の分解反応

$2 \mathrm{Nd}(\mathrm{OH})_{3} \rightarrow \mathrm{Nd}_{2} \mathrm{O}_{3}+2 \mathrm{H}_{2} \mathrm{O} \uparrow$

を経て酸化物になったと考えられる．しかし，HMT 法のもの

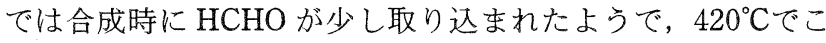
れが燃焼した点がアンモニア法のものと異なる.

尿素法の生成物が(3) 式で示したように $\mathrm{NdCO}_{3} \mathrm{OH}$ であり, $\mathrm{HMT}$ 法やアンモニア法の生成物が $\mathrm{Nd}(\mathrm{OH})_{3}$ であったのは, 沈殿剂の分解生成物における $\mathrm{CO}_{2}$ の有無が関係している。 れはTareen と Kutty ${ }^{11)}$ の $\mathrm{Nd}_{2} \mathrm{O}_{3}-\mathrm{H}_{2} \mathrm{O}-\mathrm{CO}_{2}$ 系状態図と良く一 致する。すなわち, $\mathrm{CO}_{2}$ の存在下では $\mathrm{NdCO}_{3} \mathrm{OH}$ はかなり安 定であると思われる。Tareen と Kuttyの状態図から， $\mathrm{H}_{2} \mathrm{O}$ の 存在下で $\mathrm{Nd}(\mathrm{OH})_{3}$ を加熱すると, $800 \sim 900^{\circ} \mathrm{C} て ゙ ~ \mathrm{NdOOH}$ が 生成することが予想される。しかし，反応式(7)式に示すよう に，本実験では $\mathrm{NdOOH}$ を経由しないで $\mathrm{Nd}_{2} \mathrm{O}_{3}$ となった。こ れは本実験での加熱が， $\mathrm{H}_{2} \mathrm{O}$ の少ない雾囲気で行われたため 々解釈される。

\section{3 試料の SEM 観察}

沈殿剂の濃度を变化させたときの沈殿物粒子の形状变化を 図 4 に示す。この図に見られるように，アンモニア法では, $\mathrm{Nd}\left(\mathrm{NO}_{3}\right)_{3}$ 水溶液とアンモニア水が混合された部分で直ちに沈 殿の生成が始まるため, 溶液内に濃度差が生じ粒子の大きさが 不均一となった。しかし, HMT 法と尿素法では, 沈殿剤を加 熱して初めて $\mathrm{NH}_{3}$ が生成するので, 沈殿生成を起こさせる状 態を溶液内に均一に作ることができる. そのため, 粒子の大き さは均一となった。粒子の形は, 尿素法では長さが $2.3 \sim 3.2$ $\mu \mathrm{m}$ の八面体粒子であったが, HMT 法では長さが0.5 0.7 $\mu \mathrm{m}$ の棒状粒子であり，尿素法のものに比べかなり細かいもの であった.なお、これらの沈殿物を $800^{\circ} \mathrm{C}$ な゙加熱して SEM 


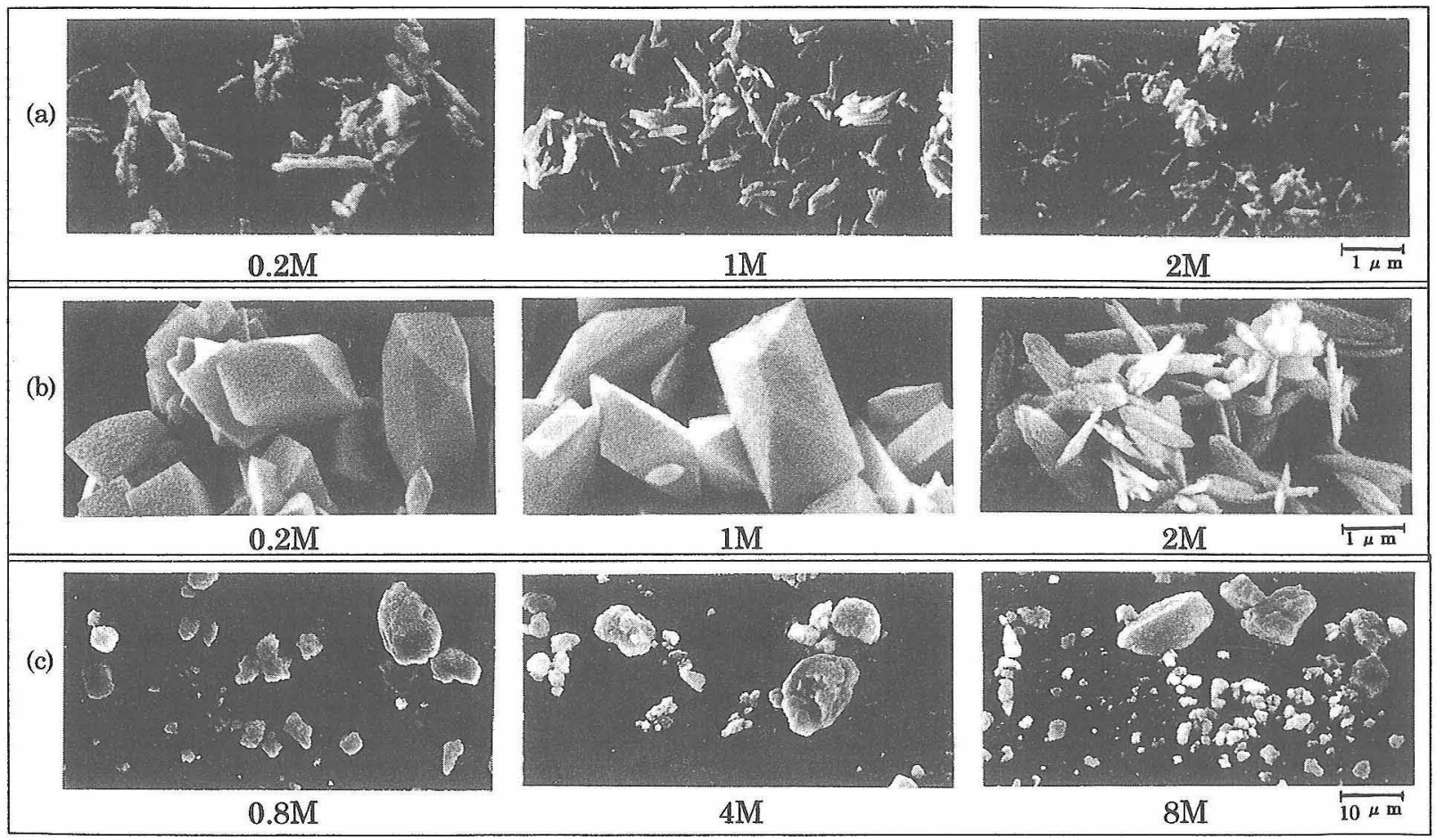

Fig. 4. SEM micrographs of particles obtained by different concentrations of precipitant: (a) HMT method, (b) urea method and (c) $\mathrm{NH}_{4} \mathrm{OH}$ method.

で観察したが，粒子の大きさや形に変化は見られなかった。

図 4 では沈殿剂の濃度が高いと粒子が細かくなることが分 かる.これは，濃度が高いと沈殿剤が多量に加水分解を起こす ことが原因であると考えられる。加水分解量が多ければ，溶液 中には $\mathrm{NaCO}_{3} \mathrm{OH} や \mathrm{Nd}(\mathrm{OH})_{3}$ の結晶核が多量に生じる。しか し, $\mathrm{Nd}\left(\mathrm{NO}_{3}\right)_{3}$ の濃度は同じなので，沈殿が大きくなる前に溶 液中の $\mathrm{Nd}^{3+}$ がなくなり，細かい粒子となってしまったと思わ れる。

\section{4 試料の焼結}

図 5 に成形体の焼結後の相対密度（かさ密度）上収縮率の結 果を示す。アンモニア法の試料では, 焼結温度が高くなっても 相対密度に著しい变化が見られず，すべての温度でかなり低い 値となった。なた，収縮率においても著しい変化は見られな

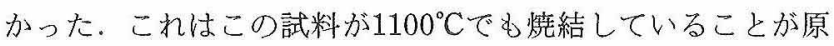
因と思われる。つなり，アンモニア法の試料では $1100^{\circ} \mathrm{C} よ り$
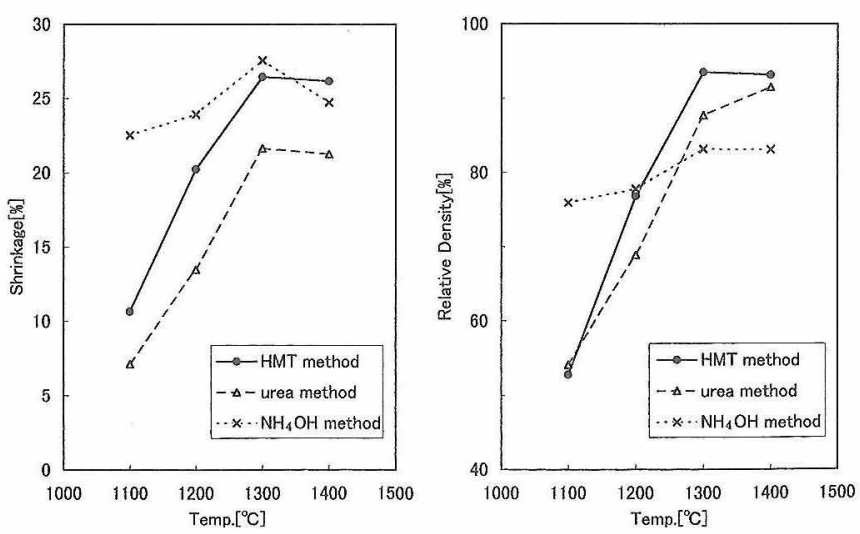

Fig. 5. Shrinkage and relative density (bulk density) of sintered compacts (theoretical density $=7.327 \mathrm{~g} / \mathrm{cm}^{3}$ ).
も低温で焼結し始めたため, 高温では駆動力がなくなり, 温度 による違いが見られなかったと考えられる，それにもかかわら ず，高い相対密度が得られなかったのは，アンモニア法で得ら れた粉末粒子が，図 4 に見られるように合成段階で部分的に 凝集していることが原因と考えられる，凝集した部分は，低温 でも焼結したが、この部分は大きな粒子となって，それ以上焼 結せず，相対密度が上がらなかったと考えられる．な拉，アン モニア法の未焼結成形体は非常に脆く，本実験においても加熱 時に,ひび割れを起こしてしまった。

HMT 法々尿素法の試料では（図 5), 焼結温度の上昇とと もに相対密度と収縮率は共に著しく上昇しており， $1300^{\circ} \mathrm{C} 以$ 上ではほぼ一定となっている。これは $1300^{\circ} \mathrm{C} て ゙$ 焼結がかなり 進行していることを示している。これらの試料では粒子の大き さが均一なのでアアンモニア法のめのより良く焼結したと思わ れる。な衫，1300〜 $1400^{\circ} \mathrm{C}$ 焼結において HMT法の試料の 相対密度が最も高く，次いで尿素法のものとなった。これは， HMT 法で得られた粉末粒子が尿素法の粒子よりも細かいため 焼結しやすく, 高密度になったものと考えられる。このことは Chen 上Chen ${ }^{10)}$ が酸化セリウムの焼結に打いて, 粒子の細か い方が良く焼結したと報告していることと類似している。高密 度焼結体を得る立場から考えると，三つの合成法の中では， HMT 法が最も良い方法であると結論できる。

\section{4. 結 論}

$\mathrm{Nd}\left(\mathrm{NO}_{3}\right)_{3}$ 水溶液に尿素水溶液, $\mathrm{HMT}$ 水溶液, あるいは $\mathrm{NH}_{4} \mathrm{OH}$ を加えて沈殿を生成し，それらをTG-DTA，XRD， IR, SEM，燒結などで評価した結果，以下のことが分かった。

(1) HMT 法とアンモニア法の沈殿物は $\mathrm{Nd}(\mathrm{OH})_{3}$ であっ たのに対し, 尿素法では加水分解時に $\mathrm{CO}_{2}$ が発生するため, $\mathrm{NaCO}_{3} \mathrm{OH}$ を生成した.このように $\mathrm{CO}_{2}$ の有無で, 沈殿物に 違いが生じた。 
（2） HMT 法とアンモニア法の沈殿物を加熱すると, $\mathrm{Nd}(\mathrm{OH})_{3} \rightarrow \mathrm{Nd}_{2} \mathrm{O}_{3}$ (立方晶) $\rightarrow \mathrm{Nd}_{2} \mathrm{O}_{3}$ (六方晶) と変化した. 尿素法の試料は, $\alpha-\mathrm{NdCO}_{3} \mathrm{OH} \rightarrow \mathrm{Nd}_{2} \mathrm{O}_{2} \mathrm{CO}_{3} \rightarrow \mathrm{Nd}_{2} \mathrm{O}_{3}$ (立方晶) $\rightarrow \mathrm{Nd}_{2} \mathrm{O}_{3}$ (六方晶) と変化した.

（3）アソモニア法では局部沈殿を起こすため沈殿物の粒子 の大きさは不均一となったが，HMT 法や尿素法では均一沈殿 のため粒子の大きさは均一となった。 また，尿素法の粒子は 2.3 3.2 $\mu \mathrm{m}$ と大きく均一であったが HMT 法の粒子は0.5 $\mu \mathrm{m}$ と細かいものであった。

（4）試料を $1100 \sim 1400^{\circ} \mathrm{C}$ で焼結すると，アンモニア法の試 料の密度は温度にあまり依存せず，80\%ぐらいであった。尿 素法, HMT 法の試料の密度は温度とともに高くなり，特に $1300 \sim 1400^{\circ} \mathrm{C}$ において HMT 法のものが最も高くなった. $\mathrm{Nd}_{2} \mathrm{O}_{3}$ の高密度焼結体を得るには, HMT 法が一番良い合成法 である。

\section{文献}

1) E. A. Barringer and H. K. Bowen, J. Am. Ceram. Soc., 65, C199-201 (1982)

2) 池本 正, 植松敬三, 水谷惟恭, 加藤誠軌, 窯協, 93, 26166 (1985)

3）セラミックス編集委員会基礎工学講座小委員会編，“セラ ミックスの製造プロセス一粉末調製と成形一”, 日本セラ ミックス協会 (1992) pp. 17-33.

4) H. H. Willard and N. K. Tang, J. Am. Chem. Soc., 59, 119096 (1937).

5) B. C. Cornilsen and J. S. Reed, Am. Ceram. Soc. Bull., 58, 1199 (1979)

6) J. E. Blendell, H. K. Bowen and R. L. Coble, Am. Ceram. Soc. Bull., 63, 797-802 (1984).

7）永島聡子, 小川友成, 加藤昭夫, J. Ceram.Soc.Japan, 102, 309-11 (1994).

8) M. Akinc and D. Sordelet, Adv. Ceram. Mater., 2[3A], 23238 (1987).

9) K. Fujita and I. Kayama, Yogyo-Kyokai-Shi, 88, 619-23 (1980).

10) P.-L. Chen and I.-W. Chen, J. Am. Ceram. Soc., 76, 1577-83 (1993)

11) J. A. K. Tareen and T. R. N. Kutty, J. Cryst. Growth, 50, 527-32 (1980). 